DOI 10.31558/2307-2318.2019.1.13

УДК 324.351

Безпалько О.М., аспірант, Донецький національний університет імені Василя Стуса

\title{
РОЛЬ ТЕРИТОРІАЛЬНИХ ГРОМАД У \\ ЗАБЕЗПЕЧЕННІ МІСЦЕВОГО ЕКОНОМІЧНОГО РОЗВИТКУ: ТЕОРЕТИЧНІ ЗАСАДИ ДОСЛІДЖЕННЯ
}

У статті визначено теоретичні засади дослідження об'єднання територіальних громад. За результатами проведеного дослідження встановлено, що за сучасних умов розвитку економіки, коли все більш наочно проявляються тенденції до погіршення економічної ситуації та загострення фінансової кризи, досягнення стратегічних цілей держави неможливо без залучення додаткових джерел наповнення місцевих бюджетів. Доведено, що вирішенню зазначених проблем сприятиме створення добровільних об'єднань територіальних громад. Проаналізовано основні підходи до визначення сутності поняття територіальної громади, та визначено, що вона розглядається як первинний суб'єкт місцевого самоврядування, який приймає безпосередню або опосередковану участь у вирішенні питань місцевого значення. Обгрунтовано, що об’єднана територіальна громада - це громада, яка спроможна через відповідні органи місцевого самоврядування забезпечити для своїх жителів належний рівень освіти, культури, охорони здоров'я, соціального захисту, житлово-комунального господарства на основі нової моделі фінансово-економічного забезпечення. Встановлено, що для підвищення ефективності реформи місцевого самоврядування необхідно забезпечити: перегляд та формування перспективного плану об'єднання територіальних громад 3 максимальним урахуванням географічної, культурної, етнічної та іншої специфіки громад; інформаційно-роз'яснювальний супровід процесу об'єднання територіальних громад; проведення навчальних семінарів для працівників органів місцевого самоврядування та громадськості щодо різних аспектів реформи.

Ключові слова: територіальна громада, об’єднана територіальна громада, модель розвитку територіальної громади, економічна модель, стратегічне планування, розвиток, економічний розвиток, управління громадою.

\section{Безпалько О.М.}

\section{РОЛЬ ТЕРРИТОРИАЛЬНЫХ ОБЩИН В ОБЕСПЕЧЕНИИ МЕСТНОГО ЭКОНОМИЧЕСКОГО РАЗВИТИЯ: ТЕОРЕТИЧЕСКИЕ ОСНОВЫ ИССЛЕДОВАНИЯ}

В статье определены теоретические основы исследования объединения территориальных общин. По результатам проведенного исследования установлено, что в современных условиях развития экономики, когда все более наглядно проявляются тенденции к ухудшению экономической ситуации и обострения финансового кризиса, достижение стратегических целей государства невозможно без привлечения дополнительных источников наполнения местных бюджетов. Доказано, что решению указанных проблем будет способствовать создание добровольных объединений территориальных общин. Проанализированы основные подходы к определению сущности понятия территориальной общины, и определено, что она рассматривается как первичный субъект местного самоуправления, принимает непосредственное или опосредованное участие в решении вопросов местного значения. Обосновано, что объединенная территориальная община - это община, которая способна через органы местного самоуправления обеспечить для своих жителей надлежащий уровень 
образования, культуры, здравоохранения, социальной защиты, жилищнокоммунального хозяйства на основе новой модели финансово-экономического обеспечения. Установлено, что для повышения эффективности реформы местного самоуправления необходимо обеспечить: просмотр и формирование перспективного плана объединения территориальных общин с максимальным учетом географической, культурной, этнической и иной специфики общин; информационно-разъяснительный сопровождение процесса объединения территориальных общин; проведение обучающих семинаров для работников органов местного самоуправления и общественности по различным аспектам реформы.

Ключевые слова: территориальная община, объединенная территориальная община, модель развития территориальной общины, экономическая модель, стратегическое планирование, развитие, экономическое развитие, управление обществом.

\section{Bezpalko O.M.}

\section{THE ROLE OF TERRITORIAL COMMUNITIES IN PROVIDING LOCAL ECONOMIC DEVELOPMENT: THEORETICAL PRINCIPLES OF THE STUDY}

The article defines the theoretical foundations of the study of the association of territorial communities. According to the results of the study, it was found that under the current conditions of economic development, when trends tend to deteriorate the economic situation and exacerbate the financial crisis, it is impossible to achieve the strategic goals of the state without attracting additional sources of local budgets. It is proved that the solution of these problems will be facilitated by the creation of voluntary associations of territorial communities. The basic approaches to the definition of the essence of the notion of a territorial community are analyzed, and it is determined that it is considered as the primary subject of local selfgovernment, which directly or indirectly participates in solving local issues. It is substantiated that the united territorial community is a community that is capable of providing adequate education, culture, health, social protection, housing and communal services for its inhabitants on the basis of a new model of financial and economic provision through the relevant local selfgovernment bodies. It is established that in order to improve the effectiveness of the reform of local self-government, it is necessary to ensure: revision and formation of a long-term plan for the association of territorial communities with maximum consideration of geographical, cultural, ethnic and other specifics of communities; information and explanatory support of the process of association of territorial communities; conducting training seminars for local government officials and the public on various aspects of reform.

Keywords: territorial community, united territorial community, model of development of the territorial community, economic model, strategic planning, development, economic development, community management.

Постановка проблеми. Задача забезпечення умов для гармонійного розвитку держави та ії регіонів завжди $є$ актуальною, що обумовлено комплексом обставин. Поперше, трендом розвинутих країн $є$ концентрація ресурсів та уваги населення на локальному рівні, обмеженому ареалом життєдіяльності, який має включати комфортні умови для життя, зайнятості та задоволення інших ключових потреб сучасних родин. Подруге, значною залишається проблема надмірної диференціації населення України за рівнем життя, зокрема в територіальному вимірі, що орієнтує державну регіональну політику на подолання територіальних відмінностей в умовах життєдіяльності людей. 
По-третє, не втрачає актуальності задача забезпечення кожному громадянину рівного доступу до матеріальних та духовних благ і послуг, у тому числі на засадах раціональної організації мережі об'єктів економічного та соціального призначення. Задача створення умов для місцевого економічного розвитку сьогодні в Україні також вирішується на державному рівні - в ході розробки та реалізації державної регіональної політики, спрямованої на надання населенню високоякісних доступних публічних послуг, розвиток соціальної інфраструктури, функціонування якої сприятиме задоволенню особистих потреб щодо гідних умов життєдіяльності та інтелектуального розвитку людей на тій чи іншій території. При цьому визначальною є орієнтація на раціональне використання ресурсів цієї території, що відповідає проголошеному принципу децентралізації.

Ідея децентралізації базується на вищезазначених тезах та створює додаткові ресурси для врегулювання поточних загальнонаціональних проблем (прояви погіршення економічної ситуації, фінансової кризи, соціальної напруженості) через реорганізацію системи наповнення місцевих бюджетів на основі поширення механізму створення добровільних об'єднань територіальних громад. Саме тому визначення теоретичних і практичних проблем становлення та функціонування об'єднаних територіальних громад в Україні $є$ актуальним напрямом дослідження.

Аналіз останніх досліджень та публікацій. У науковій літературі дослідженню проблем місцевого самоврядування, у тому числі з'ясуванню ролі держави у сфері місцевого розвитку присвячено праці В. Бабаєва [1], О. Батанова [2], В. Борденюка, I. Борденюк, П. Ворони, П. Гураль, М. Гірняк, В. Дрешпака, І. Дробота [3], I. Дробуш, I. Ковалевич, І. Козюри, В. Кравченка, В. Мамонової [4], В. Новик, О. Петришин, М. Пухтинського, С. Серьогіна, А. Ткачук, І. Залуцького, Н. Камінської, М. Лендьєл, А. де Токвіля та ін. Змістовні дослідження методологічних засад управління розвитком територіальних самоврядних спільнот низового рівня провів О. Панухник, переважно зосередившись на селищних громадах. Окремі функціональні механізми управління розвитком міст досліджуються у працях Р. Брусака, Г. Дробенка, В. Куибіди, О. Невелєва, І. Салія, Ю. Свірського, Ю. Шарова. Моделюванню та удосконаленню механізмів управління соціо-еколого-економічними системами присвячені роботи О. Амоші, В. Василенка, В. Вітлінського, В. Гейця, О. Гранберга, Т. Клебанової, В. Максимова, С. Рамазанова та ін. В той же час недостатньо дослідженими та переважно невирішеними в практичній площині $є$ питання становлення та розвитку місцевого самоврядування, є потреба у систематизації умов для набуття сили й економічного потенціалу територіальними громадами та забезпечення ефективності процесів їх об'єднання.

Метою дослідження $є$ узагальнення теоретичного досвіду дослідників щодо розвитку територіальних громад, виокремлення типових рис територіальних громад, аналізу процесів їх об'єднання та систематизація базових категорій дослідження.

Виклад основного матеріалу дослідження. Реформа місцевого самоврядування та територіальної організації влади на засадах децентралізації, концептуальні засади якої були схвалені у 2014 році [5], а практична реалізація розпочалась у 2015 році, стала однією 3 найрезультативніших і найпомітніших серед стратегічних реформ. Реформа децентралізації спрямована на створення сучасної системи місцевого самоврядування в Україні на основі європейських цінностей розвитку місцевої демократії, наділення територіальних громад повноваженнями та ресурсами, що забезпечать місцевий економічний розвиток, надання населенню високоякісних та доступних публічних 
послуг. Роль об'єднаних територіальних громад у забезпеченні інтересів громадян в усіх сферах життєдіяльності на відповідній території має стати ключовою.

Основний напрям реформ передбачає не посилення управлінської вертикалі в регіонах, а формування локальних «центрів відповідальності» для впорядкування суспільного життя та забезпечення територіального економічного розвитку. При цьому в регіонах має відбутися розмежування повноважень державного управління та місцевого самоврядування, що має бути забезпечено відповідним зміцненням самоврядування щодо самостійності у прийнятті рішень та їхньої реалізації, у першу чергу на базовому рівні - рівні об'єднаних територіальних громад [6].

Основою місцевого самоврядування в Україні є територіальні громади. Отже, від того, як розвиватимуться територіальні громади, яку роль вони будуть відігравати в житті кожного регіону, кожної людини та всієї держави та наскільки коректно та обгрунтовано будуть проведені процеси створення «спроможних» об'єднаних територіальних громад, і залежатиме майбутній розвиток України та успіх реформ.

Управління розвитком населеного пункту здійснюється через інститут місцевого самоврядування. Місцеве самоврядування являє собою систему організації влади на місцевому рівні, за якої місцеві громади набувають реальної можливості в різний спосіб самостійно і незалежно від держави вирішувати проблеми, що стосуються організації їх життєдіяльності. Основою місцевого самоврядування є територіальна громада - його первинний суб'єкт, тобто населення, яке, внаслідок природного розселення, мешкає на певній території й має право вирішувати свої інтереси місцевого рівня [7].

Поняття «територіальна громада» $є$ предметом дослідження багатьох науковців. Основні підходи до визначення сутності поняття «територіальна громада» представлено у табл. 1 .

Таблиця 1

Підходи до трактування сутності поняття «територіальна громада»

\begin{tabular}{|c|c|}
\hline Автор & Визначення \\
\hline 1 & 2 \\
\hline $\begin{array}{l}\text { Батанов О.В. } \\
{[2, \text { с. } 52]}\end{array}$ & $\begin{array}{l}\text { Територіальна громада - це первинний суб’єкт місцевого самоврядування, } \\
\text { що складається з фізичних осіб - жителів (громадян України, іноземних } \\
\text { громадян, осіб без громадянства, біженців, вимушених переселенців), що } \\
\text { постійно мешкають, працюють на території села (або добровільного } \\
\text { об’єднання в спільну громаду кількох сіл), селища або міста, } \\
\text { безпосередньо або через сформовані ними муніципальні структури } \\
\text { вирішують питання місцевого значення, мають спільну комунальну } \\
\text { власність, володіють на певній території нерухомим майном, сплачують } \\
\text { комунальні податки та пов'язані індивідуальними територіальними } \\
\text { зв'язками системного характеру. }\end{array}$ \\
\hline $\begin{array}{l}\text { Орзіх М.П. } \\
{[8 ; 9]}\end{array}$ & $\begin{array}{l}\text { Територіальна громада - первинний суб’єкт місцевого самоврядування, } \\
\text { єдиний на території соціальний субстрат, який має власні інтереси, до } \\
\text { складу якого входять громадяни України, іноземці, особи без } \\
\text { громадянства, щ постійно мешкають або працюють на даній території, або } \\
\text { володіють на території нерухомим майном, або сплачують місцеві податки } \\
\text { та збори. }\end{array}$ \\
\hline $\begin{array}{l}\text { Баймуратов } \\
\text { M.O. [10] }\end{array}$ & $\begin{array}{l}\text { Територіальна громада - сукупність фізичних осіб, що постійно мешкають } \\
\text { на відповідній території та пов'язані між собою територіально-особистими } \\
\text { зв'язками системного характеру. }\end{array}$ \\
\hline
\end{tabular}


Продовження таблиці 1

\begin{tabular}{|c|c|}
\hline 1 & 2 \\
\hline $\begin{array}{l}\text { Гейда О.В. } \\
{[11, \text { с. 13] }}\end{array}$ & $\begin{array}{l}\text { Територіальна громада є поліструктурним об’єднанням. Визначальною } \\
\text { ознакою, за якою законодавець поділяє територіальні громади на види, є } \\
\text { адміністративно-територіальний устрій нашої держави згідно } 3 \\
\text { положеннями Основного Закону та Закону України «Про місцеве } \\
\text { самоврядування в Україні». Існує три їх види: територіальна громада села } \\
\text { або добровільного об’єднання в сільську громаду жителів кількох сіл; } \\
\text { територіальну громаду селища; територіальну громаду міста. }\end{array}$ \\
\hline $\begin{array}{l}\text { Конституція } \\
\text { України (ст. } \\
\text { 140-143) [12] }\end{array}$ & $\begin{array}{l}\text { Територіальна громада - це жителі одного чи декількох населених пунктів, } \\
\text { які добровільно об’єднуються в одну територіальну громаду для вирішення } \\
\text { питань місцевого значення, а саме: обирають сільського, селищного чи } \\
\text { міського голову, який очолює виконавчий орган ради та головує на } \\
\text { засіданнях виконавчого комітету та ради, старост та депутатів ради, які } \\
\text { представляють та захищають інтереси всієї громади; управляють майном, } \\
\text { що є в комунальній власності; затверджують програми соціально- } \\
\text { економічного та культурного розвитку і контролюють їх виконання; } \\
\text { затверджують бюджети відповідних адмністративно-територіальних } \\
\text { одиниць і контролюють ї виконання; встановлюють місцеві податки і } \\
\text { збори відповідно до закону; забезпечують проведення місцевих } \\
\text { референдумів та реалізацію їх результатів; утворюють, реорганізовують та } \\
\text { ліквідовують комунальні підприємства, організації і установи, а також } \\
\text { здійснюють контроль за їх діяльністю; вирішують інші питання місцевого } \\
\text { значення, віднесені законом до їхньої компетенції. }\end{array}$ \\
\hline $\begin{array}{l}\text { Цивільний } \\
\text { кодекс України } \\
\text { [13] }\end{array}$ & $\begin{array}{l}\text { Територіальні громади є юридичними особами, мають свої рахунки, } \\
\text { надходження..., можуть створювати комунальні підприємства, навчальні } \\
\text { заклади, підприємницькі товариства, приймати участь в їх діяльності на } \\
\text { загальних підставах. }\end{array}$ \\
\hline $\begin{array}{l}\text { Свропейська } \\
\text { хартія } \\
\text { місцевого } \\
\text { самоврядування } \\
\text { [14] }\end{array}$ & $\begin{array}{l}\text { Одним із специфічних суб’єктів місцевого самоврядування є територіальна } \\
\text { громада. Її специфіка полягає в тому, що на місцевому рівні можна } \\
\text { розглядати перетворення територіальної громади з учасника управління на } \\
\text { його первинного суб'єкта. Як відомо, під управлінням розуміють будь-який } \\
\text { цілеспрямований вплив суб'єкта управління на об’єкт управління. Але в } \\
\text { умовах самоврядування очевидно сильнішим є вплив управлінської системи } \\
\text { самої на себе. Отже, є не дві системи - управлінська і та, якою управляють, } \\
\text { а одна - самоуправлінська. Самостійність місцевого самоврядування, що } \\
\text { знаходить свій вияв у організаційній і матеріально-фінансовій } \\
\text { відокремленості, самостійному вирішенні місцевих справ у рамках } \\
\text { компетенції, закріпленої законодавством, самостійній відповідальності } \\
\text { органів і посадових осіб місцевого самоврядування. }\end{array}$ \\
\hline $\begin{array}{l}\text { Закон України } \\
\text { «Про місцеве } \\
\text { самоврядування } \\
\text { в Україні» (ст. } \\
\text { 6) [7] }\end{array}$ & $\begin{array}{l}\text { Первинним суб'єктом місцевого самоврядування, основним носієм його } \\
\text { функцій і повноважень є територіальна громада села, селища, міста; } \\
\text { територіальні громади в порядку, встановленому законом, можуть } \\
\text { об'єднуватися в одну сільську, селищну, міську територіальну громаду, } \\
\text { утворювати єдині органи місцевого самоврядування та обирати відповідно } \\
\text { сільського, селищного, міського голову; територіальні громади села, } \\
\text { селища, міста, що добровільно об'єдналися в одну територіальну громаду, } \\
\text { можуть вийти із складу об'єднаної територіальної громади в порядку, } \\
\text { визначеному законом. }\end{array}$ \\
\hline $\begin{array}{l}\text { Енциклопедія } \\
\text { державного } \\
\text { управління [15] }\end{array}$ & $\begin{array}{l}\text { Територіальна громада - це спільнота людей, об'єднаних різноманітними } \\
\text { стійкими формальними та неформальними зв’язками, які обумовлені } \\
\text { спільним проживанням у межах села, селища, міста. }\end{array}$ \\
\hline
\end{tabular}


Таким чином, аналіз визначень поняття «територіальна громада» дає підстави стверджувати, що вона розглядається як первинний суб'єкт місцевого самоврядування, який приймає безпосередню або опосередковану участь у вирішенні питань місцевого значення.

Реформа місцевого самоврядування передбачає об'єднання (укрупнення) територіальних громад, забезпечення їх спроможності самостійно, за рахунок власних ресурсів вирішувати питання місцевого значення. Нормативними підставами реформування місцевого самоврядування є Закон України «Про добровільне об'єднання територіальних громад» [16] та урядові документи: Концепція реформування місцевого самоврядування та територіальної організації влади в Україні [5]; Методика формування спроможних територіальних громад [17]. Саме ці акти визначають, у який спосіб має відбуватись об'єднання громад, для того щоб вони стали спроможними.

Відповідно до затвердженої Методики, «спроможна територіальна громада - це територіальні громади сіл (селищ, міст), які в результаті добровільного об'єднання здатні самостійно або через відповідні органи місцевого самоврядування забезпечити належний рівень надання послуг, зокрема у сфері освіти, культури, охорони здоров'я, соціального захисту, житлово-комунального господарства, з урахуванням кадрових ресурсів, фінансового забезпечення та розвитку інфраструктури відповідної адміністративнотериторіальної одиниці» [17]. Тобто спроможною територіальною громадою $є$ така громада, у якій місцеві джерела наповнення бюджету, інфраструктурні та кадрові ресурси є достатніми для вирішення ії органами місцевого самоврядування питань місцевого значення, передбачених законодавством, в інтересах жителів громади.

Об'єднані територіальні громади характеризують як первинні адміністративнотериторіальні одиниці та базові ланки адміністративно-територіального устрою України. Об'єднані громади утворюються внаслідок добровільного об'єднання суміжних територіальних громад сіл, селищ, міст. Об'єднана територіальна громада, адміністративним центром якої визначено місто, $є$ міською територіальною громадою, центром якої визначено селище міського типу, - селищною, центром якої визначено село, - сільською. На рівні об'єднаних територіальних громад зосереджуються значні ресурси, що забезпечують зростання економіки, сприяють формуванню ефективного управлінського впливу та підвищенню рівня соціального добробуту мешканців.

Тобто, об'єднана територіальна громада - це громада, яка спроможна через відповідні органи місцевого самоврядування забезпечити для своїх жителів належний рівень освіти, культури, охорони здоров'я, соціального захисту, житлово-комунального господарства, включаючи економічно-фінансові спроможності розвитку.

Реформуючи систему місцевого самоврядування, Україна вирішила піти шляхом добровільності об'єднання громад, водночас створивши умови чітких стимулів та заохочень для громад, які пройдуть цей процес об'єднання. Об'єднана територіальна громада фінансуватиметься на таких самих засадах, як і нинішні міста обласного значення. За ними закріплюється 60\% податку на доходи фізичних осіб. Це кошти на утримання дитячих садочків, шкіл, ФАПів, клубів, бібліотек, спортивних споруд тощо. Держава надаватиме субвенції на освіту, медицину, а за нестачі коштів - дотацію вирівнювання. Окрім цього, держава ще стимулюватиме громади, які вирішили добровільно об'єднатися, додатково виділятиме кошти та сприятиме залученню міжнародних фінансів для проектів із реконструкції закладів бюджетної сфери. Самоврядна територіальна громада автономно розпоряджатиметься своїми фінансами, тому бюджетні кошти розподілятимуться раціональніше. Крім цього, рада громади визначатиме скільки їй потрібно службовців, призначатиме їм зарплати та ін. 
Висновки. Таким чином, в процесі дослідження визначено, що об'єднана територіальна громада - це громада, яка спроможна через відповідні органи місцевого самоврядування забезпечити для своїх жителів належний рівень освіти, культури, охорони здоров'я, соціального захисту, житлово-комунального господарства на основі нової моделі фінансово-економічного забезпечення, яке передбачає концентрацію та раціональне використання ресурсів на локальному рівні. Для підвищення ефективності реформи місцевого самоврядування необхідно забезпечити: перегляд та формування перспективного плану об'єднання територіальних громад з максимальним урахуванням географічної, культурної, етнічної та іншої специфіки громад; інформаційнороз'яснювальний супровід процесу об'єднання територіальних громад; проведення навчальних семінарів для працівників органів місцевого самоврядування та громадськості щодо різних аспектів реформи. Перспективами подальших досліджень можуть бути вивчення та узагальнення досвіду процесів об'єднання територіальних громад в Україні.

\section{СПИСОК ВИКОРИСТАНИХ ДЖЕРЕЛ}

1. Бабаєв В. М. Управління великим містом: теоретичні і прикладні аспекти: монографія. Харків: Харків. нац. акад. міськ. госп-ва, 2010. 306 с.

2. Батанов О. В. Територіальна громада - первинний суб'єкт муніципальної влади в Україні: поняття та ознаки. Вісник Центральної виборчої комісії. 2008. №2 (12). С.51-57. 3. Дробот I. О. Гарантування місцевого самоврядування в Україні: теорет.-методол. ас-пект: монографія. Львів: ЛРІДУ НАДУ, 2010. 312 с.

4. Територіальна громада: знаннєвість, дієвість: монографія / Ю. О. Куц, В. М. Сінченко, В. В. Мамонова та ін.; за заг. ред. Ю. О. Куца. Харків: Віровець А. П.; Апостроф, 2011. 340 с.

5. Про схвалення Концепції реформування місцевого самоврядування та територіальної організації влади в Україні: Постанова Кабінету Міністрів України від 1 квіт. 2014 р. № 333-p. URL: http://zakon4.rada.gov.ua/laws/show/333-2014-\%D1\%80.

6. Білуха Л. А. Поняття територіальної громади та спроможної територіальної громади. Теорія та практика державного управління. 2017. № 1 (56). С. 1-6.

7. Закон України «Про місцеве самоврядування в Україні» № 280/97 від 21 трав. 1997 р. ВВР України. 1997. № 24. Ст. 170.

8. Орзих М. Ф. Регионализм в Украине: критический анализ современной ситуации. Юридический вестник. 1996. №4. С. 64.

9. Орзіх М. П. Концепція правового статусу самоврядних територій і органів місцевого самоврядування. Місцеве та регіональне самоврядування України. К., 1995. Вип. 1-2 (10-11). С. 67.

10. Баймуратов М. А. Европейские стандарты локальной демократии и местное самоуправление в Украине. Х., 2000. С. 8.

11. Гейда О. В. Види територіальних громад в Україні та особливості їх правового статусу: загальна характеристика. Європейські перспективи. 2012. №3 (3). С. 9-13.

12. Конституція України. URL: http://zakon3.rada.gov.ua/laws/show/ 254\%D0\%BA/96\%D0\%B2\%D1\%80/print 1473849831326174.

13. Цивільний кодекс України. URL: http://kodeksy.com.ua/tsivil_nij_kodeks_ukraini/statja-169.htm.

14. Свропейська хартія місцевого самоврядування. Страсбург, 15 жовт. 1985 р. Хартію ратифіковано Законом № 452/97-ВР від 15 лип. 1997 p. URL: http://zakon1.rada.gov.ua/laws/show/994_036. 
15. Лиска О. Г. Територіальна громада. Енциклопедія державного управління: у 8 т. / наук.-ред. колегія: Ю. В. Ковбасюк (голова) та ін.; Нац. акад. держ. упр. при Президентові України. Т. 5: Територіальне управління / наук.-ред. колегія: О. Ю. Амосов (співголова), О. С. Ігнатенко (співголова) та ін.; за ред. О. Ю. Амосова, О. С. Ігнатенка, А. О. Кузнецова. Харків: Вид-во ХарРІ НАДУ “Магістр”, 2011. С. 378.

16. Закон України “Про добровільне об'єднання територіальних громад”. URL: zakon.rada.gov.ua/laws/show/157-19.

17. Методика формування спроможних територіальних громад. URL: oblrada.dp.ua/user/files/Metodika formyvannya ter gromad.pdf. 